\title{
ANALISIS STRATEGI PEMASARAN TERHADAP PENINGKATAN VOLUME PENJUALAN PADA PT. SINAR GALESONG MAKASSAR
}

\author{
Ansir H. A. Launtu *)
}

\begin{abstract}
PT. Sinar Galesong Makassar experience of the sale degradation or equally sale of motor Suzuki with the type Smash in the year 2009 do not reach the goals, differing from year-previous year of PT. Ray of Galesong Makassar as formal dealer of motor Suzuki of exist in town Makassar master the motor market. This matter is triggered with the existence of emulation of globalization era claiming company party to run marketing strategy and ever improve the its service quality in order to reaching cutomer satisfaction. Decision taker very shall have knowledge the downhill cause it sum up the sale volume in the year 2009. This matter is not quit of perception to internal factor and factor eksternal. With the analysis SWOT will be known the : strength And weakness internally, opportunity and also threat externally To find the priority of marketing strategy applied in attainment of satisfaction of cutomer used by Value Analyse the Strategy. From result value analyse the inferential strategy that is : priority of marketing Strategy selected to increase service quality of at PT. Sinar Galesong Makassar Makassar. Parameter selected to in to comparing is determinant representing organizational performance key of competitor. From comparison result will be able to be known by the difference of result of calculation of among PT. Sinar Galesong Makassar by PT. Nusantara Surya Sakti as competitor coming near to mean the repair plan short-range, while difference which is long-range far
\end{abstract}

Keyword : Analisa SWOT, Value Analisis Strategi

\section{PENDAHULUAN}

\subsection{Latar Belakang}

PT. Sinar Galesong Makassar adalah suatu perusahaan yang bergerak dalam bidang penjualan dan penyedia jasa servis kendaraan bermotor roda dua , dimana PT. Sinar Galesong Makassar merupakan salah satu jaringan penjualan dan bengkel resmi Suzuki untuk wilayah kota Makassar dan sekitarnya. PT. Sinar Galesong Makassar boleh dikatakan dealer tunggal dalam penjualan kendaraan bermotor berlabel Suzuki di kota Makassar. Sejak didirikannya pada tahun 2001 penjualannya selalu mencapai target sampai tahun 2008 dimana penjualan mencapai 746 unit/tahun. Pada periode penjualan tahun 2009 perusahaan tidak mencapai target yang ditetapkan yaitu 825 uni/tahun, dimana penjualannya hanya mencapai 462 unit/tahun

Tidak tercapainya target penjualan ini disebabkan antara lain : perusahaan hanya menerapkan strategi defensive/saller mar- ket, adanya pesaing atau perusahaan baru dengan penjualan produk yang sama yaitu PT. Nusantara Surya Sakti, selain sebagai dealer penjualan motor PT.Sinar Galesong Makassar juga melayanui jasa servis kendaraan bermotor yang mana dituntut untuk memberikan pelayanan yang baik kepada konsumen serta kondisi internal manajemen perusahaan yang tidak dikelola dengan baik.

Agar unggul dalam bersaing, perusahaan harus memperhatikan banyak faktor antara lain faktor internal dan factor eksternal perusahaan. Sehubungan dengan hal diatas mulai dari pimpinan perusahaan berupaya melakukan rencana perbaikan strategi penjualan baik jangka pendek maupun jangka panjang. Pada penelitian ini digunakan analisa SWOT untuk menentukan strategi yang tepat dalam melakukan pemasaran penjualan kendaraan bermotor pada PT. Sinar Galesong Makassar. Dengan analisa SWOT akan diketahui kekuatan dan kelemahan secara internal, peluang dan ancaman secara eksternal. 
Setelah hal tersebut diatas diketahui baru menetapkan strategi yaitu :Peluang dengan kekuatan, ancaman dengan kekuatan, peluang dengan kelemahan dan ancaman dengan kelemahan. Untuk menentukan prioritas strategi pemasaran yang diterapkan dalam pencapaian kepuasan pelanggan digunakan Value Analisis Strategi. Dari hasil value analisis strategi dapat disimpulkan prioritas strategi pemasaran yang dipilih untuk meningkatkan kualitas pelayanan pada PT. Sinar Galesong Makassar.

\subsection{Perumusan Masalah}

Berdasarkan latar belakang masalah yang telah diuraikan diatas maka pokok permasalahannya adalah bagaimana strategi pemasaran yang diterapkan berpengaruh dalam peningkatan volume penjualan pada PT. Sinar Galesong Makassar.

\subsection{Tujuan Penelitian}

Tujuan yang ingin dicapai dari penelitian ini adalah mencari alternative strategi pemasaran yang efektif untuk meningkatkan volume penjualan.

\subsection{Manfaat Penelitian}

Dari hasil penelitian yang dilakukan, diharapkan dapat memberikan sumbangan yang positif bagi perusahaan PT. Sinar Galesong Makassar, dalam hal ini dapat memberikan :

Masukan bagi pihak perusahaan PT. Sinar Galesong Makassar dalam mengambil keputusan untuk memilih strategi pemasaran yang tepat untuk meningkatkan volume penjualan.

\subsection{Batasan Masalah}

Agar penelitian dapat berfokus dengan baik sehingga tertuju pada inti permasalahan, maka perlu diberi batasanbatasan, yaitu :

1. Penelitian ini hanya untuk sepeda motor Suzuki dengan merk Smash.

2. Penelitian ini tidak membahas hal-hal yang berkaitan dengan perhitungan peramalan hasil penjualan dan penetap- an harga jual serta kondisi keuangan perusahaan.

\section{TINJAUAN PUSTAKA}

\subsection{Definisi Pemasaran}

Pemasaran adalah identifikasi, daya tarik, mendapatkan dan memelihara hubungan yang baik ("harmonis") dengan para konsumen secara saling menguntungkan, Fetterment (2004:3). Identifikasi, daya tarik dan mendapatkan sesuatu merupakan fungsi pra-penjualan. Memelihara dan membina termasuk fungsi-fungsi pasca pemasaran. Setiap fungsi pekerjaan karyawan merupakan bagian dari pengertian tentang pemasaran. Pemasaran merupakan pusat (episenter) dari suatu organisasi atau perusahaan. Pemasaran merupakan salah satu dari kegiatan-kegiatan pokok yang dialkukan oleh perusahaan untuk mendapatkan laba, berkembang dan untuk mempertahankan kelangsungan hidupnya.. Seiring dengan sejarah manusia dalam memenuhi kebutuhannya, ada pihak yang meminta dan ada pihak yang menawarkan. Pemasaran menarik perhatian yang sangat besar baik dari perusahaan, lembaga maupun antar bangsa.. Pemasaran hendaknya memberi sumbangan pada perluasan dan pemusasan kebutuhan dan keinginan manusia. Pemasaran harus merupakan sarana dari organisasi untuk mengetahui kebutuhan manusia yang tak terpenuhi, barulah menjadi peluang usaha, menciptakan pemenuhan kebutuhan yang digunakan sangat tergantung dari kemampuan untuk menciiptakan manusia yang selalu berubah. Pemasaran lebih dari sekedar kemampuan organisasi untuk memproduksi barang atau jasa dalam memenuhi kebutuhan, karena organisasi harus mengetahui bagaimana menyajikan tawaran yang lebih baik di pasar sasaran daripada para pesaing.

Menurut Sunarto (2003:7) mendefinisikan bahwa pemasaran adalah proses perencanaan dan pelaksanaan pem ${ }^{-1}$ penetapan harga, promosi serta peny 
gagasan, barang dan jasa untuk menciptakan pertukaran yang memenuhi sasaran individu dan organisasi.

Philip kotler (2002:9) definisi pemasaran dipandang dari ssegi sosial yang sesuai dengan tujuan kita yaitu pemasaran adalah suatu proses sosial yang di dalamnya individu dan kelompok mendapatkan apa yang mereka butuhkan dan inginkan dengan menciptakan, menawarkan, dan secara bebas mempertukarkan produk yang bernilai dengan pihak lain.

Untuk definisi manajerial, pemasaran sering digambarkan sebagai "seni menjual produk". Akan tetapi, orang heran ketika mereka mendengar bahwa bagian yang paling penting dari pemasaran adalah bukan penjualan. Penjualan itu hanya merupakan puncak kecil dari gunung es pemasaran.

\subsection{Pengertian Bauran Pemasaran (Marketing Mix)}

Selama ini kita sering memandang pemasaran adalah sebuah proses dimana individu atau kelompok dapat memperoleh apa yang mereka butuhkan dengan melakukan suatu pertukaran produk dan nilai Kotler-Armstrong, (2001:12). Upaya peningkatan pertukaran ini kemudian kita simpulkan dengan melakukan bauran pemasaran (Marketing Mix) yang 4P, yaitu : Product, Price, Promotion and Place.

Dari uraian di atas maka, menurut Kotler (2002, hal. 18) berpendapat bahwa bauran pemasaran adalah seperangkat alat pemasaran yang digunakan perusahaan untuk terus menerus mencapai tujuan pemasarannya di pasar sasaran. Hal itu disebabkan karena bauran pemasaran merupakan salah satu konsep utama dalam pemasaran modern. Sebagaimana yang dikemukakan oleh Angipora (2002, hal. 24) bahwa bauran pemasaran adalah perangkat variabel-varibel pemasaran terkontrol yang digabungkan perusahaan untuk menghasilkan tanggapan yang diinginkan dalam pasar sasaran, (target market). Konsep marketing mix merupakan segala usaha yang dapat dilakukan untuk mempengaruhi permintaan akan produknya.

Dalam menetapkan marketing mix harus berpegang pada prisip ekonomis yaitu dengan pengorbanan yang sekecilkecilnya ingin mendapatkan mix yang sebesar-besarnya. Maka dalam menetapkan marketing mix, dalam arti untuk mencapai target penjualan tertentu, kita harus menetapkan marketing mix yang sebaikbaiknya. Hal yang harus dipertimbangkan sebagai berikut (Tjiptono, 2002, hal. 90) :

1. Marketing mix harus seimbang

Dalam melaksanakan marketing mix secara umum haruslah diusahakan dalam keadaan seimbang. Seimbang disini adalah dalam keadaan keseimbangan yang sebaik mungkin, misalny diadakan advertensi secara besarbesaran tanpa usaha memperbaiki kualitas produksinya, maka hasil yang dicapai kurang memuaskan. Oleh sebab itu advertensi besar-besaran harus diimbangi oleh mutu produk yang baik.

2. Marketing mix tidak boleh statis

Disini marketing mix tidak boleh bersifat statis, tapi harus dinamis. Misalnya saingan mencoba meniru strategi marketing mix, yang kita lancarkan maka kita harus cepat mengatur siasat baru. Disini dituntut dinamika dan kreativitas dari manajer pemasaran.

3. Marketing mix tidak boleh meniru Dalam melaksanakan marketing mix belum tentu tepat bial satu perusahaan meniru atau menjiplak begitu saja perusahaan yang lain, sebab situasi dan kondisi perusahaan tidaklah persis sama. Apabila kita hanya meniru-niru, maka justru dapat merugikan perusahaan, misalnya marketing mix barang industri lebih dominant menggunakan personal selling, sedangkan marketing mix pada perusahaan rokok lebih banyak menggunakan iklan/reklame.

4. Marketing mix harus bertujuan jangka panjang 
Dalam melaksanakan marketing mix, maka sebaiknya diusahakan mencapai tujuan jangka panjang, hal ini tidak berarti tujuan jangka pendek diabaikan. Sebabtujuan jangka pendek ada pula yang dipakai untuk mencapai tujuan jangka panjang.

5. Marketing mix haurs disesuaikan dengan situasi dan kondisi perusahaan.

Dalam menetapkan marketing mix, maka perusahaan dapat terlebih dahulu menetapkan target omzet penjualan yang ingin dicapai. Akan tetapi dalam keadaan dana yang terbatas maka marketinmg mix ditetapkan terlebih dahulu dan baru kemudian menetapkan target penjualan yang mungkin dicapai. Selain itu marketing mix yang ditetapkan harus disesuaikan dengan situasi dan kondisi perusahaan.

6. Marketing mix harus didasarka pada pengalaman

Ada ungkapan yang terkenal yaitu pengalaman adalah guru yang baik. Berdasarka hal itu sebenarnya menetapkan marketing mix berdasarkan pengalaman-pengalaman yang lalu pada umumnya akan lebih sukses, karena dapat mengetahui kekurangan dn kelemahannya, namun hal ini akan sulit bagi perusahaan yang harus didirikan atau perusahaan yang memproduksi barang baru. Meskipun demikian perusahaan harus tetap melaksanakan marketing mix yang sebaik-baiknya.

\subsection{Unsur-unsur Bauran Pemasaran (Markeing Mix)}

Setelah memutuskan strategi pemasaran untuk bersaing secara keseluruhan, perusahaan harus siap memulai merencanakan rincian dari bauran pemasaran. Bauran pemasaran adalah salah satu konsep utama dalam pemasaran modern. Kita mendefinisikan bauran pemasaran sebagai perangkat alat pemasaran taktis yang dapat dikendalikan, yang dipadukan oleh perusahaan yang melahirkan respons yang diinginkan dalam pemasaran. Bauran pemasaran terdiri dari segala sesuatu yang dapat dilakukan perusahaan untuk mempengaruhi permintaan produknya.

Menurut Assauri (1999, hal. 181) ada empat unsur atau variabel strategi acuan/bauran pemasaran tersebut adalah :

1. Produk

2. Harga

3. Penyaluran/distribusi

4. Promosi

Keempat unsur tersebut di atas saling mempengaruhi (independent), sehingga semuanya penting sebagai satu kesatuan unsur, yaitu strategi acuan/ bauran.

\subsection{Pengertian Strategi Pemasaran}

Setiap fungsi manajemen memberikan kontribusi tertentu pada level yang berbeda. Pemasaran merupakan fungsi yang memiliki kontak paling besar dengan lingkungan eksternal, padahal perusahaan hanya memiliki kendali yang terbatas terhadap lingkungan eksternal. Oleh karena itu pemasaran memainkan peranan penting dalam pengembangan strategi. Dalam peranan strateginya, pemasaran mencakup setiap usaha untuk mencapai pemecahan atas masalah penentuan dua pertimbangan pokok yaitu:

1. Bisnis apa yang digeluti perusahaan pada saat ini dan jenis bisnis apa yang dapat dimasuki di masa mendatang.

2. Bagaimana bisnis yang telah dipilih tersebut dapat dijalankan dengan sukses dalam lingkungan yang kompetitif atas dasar perspektif produk, harga, promosi, dan distribusi untuk melayani pasar sasaran.

Dalam konteks penyusunan strategi pemasaran memiliki 2 dimensi, yaitu dimensi saat ini dan dimensi masa yang akan datang. Dimensi saat ini berkaitan dengan hubungan yang telah ada antara perusahaan dengan lingkungannya. Sedangkan dimensi masa yang akan datang mencakup hubungan di masa yang akan datang yang diharapkan akan dapat terjalin 
dan program tindakan yang diperlukan untuk mencapai tujuan tersebut.

Tjiptono (2002, hal. 6) mengemukakan pengertian strategi pemasaran, pemasaran adalah sebagai alat fundamental yang direncanakan untuk mencapai tujuan perusahaan dengan mengembangkan keunggulan bersaing yang berkesinambungan melalui pasar sasaran tersebut. Pada dasarnya strategi pemasaran memberikan arah dalam kaitannya dengan variable-variable seperti segmentasi pasar, identifikasi pasar sasaran, positioning, elemen bauran pemasaran, dan biaya bauran pemasaran.

Adapun elemen-elemen strategi pemasaran yang saling terkait yaitu :

1. Pasar, yaitu memilih pasar yang akan dilayani.

2. Perencanaan produk, meliputi produk spesifik yang dijual, pembentukan lini produk, dan desain penawaran individual pada masing-masing lini.

3. Pemilihan Penetapan harga, yaitu menentukan harga yang dapat mencerminkan nilai kuantitatif dari produk kepada pelanggan.

4. Komunikasi pemasaran (promosi), yang meliputi periklanan, personal selling, promosi penjualan, direct marketing, dan public relations.

Tjiptono (2002, hal 65) mengemukakan bahwa setiap perusahaan dalam melayani pasarnya mimiliki tiga strategi pemasaran yaitu :

1. Mass marketing (Undiffentiated Marketing)

2. Product-Variety marketing (Differentiated Marketing)

3. Target Marketing.

\subsection{Penjualan}

Menurut Henry Ford (dalam Denny 2003: xvi) penjualan didefinisikan sebagai berikut:

"Penjualan adalah suatu profesi dan harus punya etika professional memerlukan integritas profesional yang timbul dari kebaggaan bukan paksaan. Sikap mental profesional akan mendeteksi sendiri penyimpangan yang dilakukan dan memberi hukuman terhadapnya".

\subsection{Analisis SWOT}

Merupakan identifikasi berbagai faktor secara sistematis untuk merumuskan strategi perusahaan. Analisa ini didasarkan pada suatu logika yang dapat memaksimalkan kekuatan (Strengths) dan peluang (Opportunities), namun secara bersamaan dapat juga untuk meminimalkan kelemahan (Weaknesses) dan ancaman (Threats).

Untuk proses pengambilan keputusan strategis selalu berkaitan dengan pengembangan misi, tujuan, strategi, dan kebijaksanaan perusahaan. Perencanaan strategis (strategic planner) harus menganalisa faktor-faktor strategis perusahaan (kekuatan, kelemahan, peluang, dan ancaman) dalam kondisi yang ada pada saat ini. Hal inilah yang disebut analisis situasi.

Analisis SWOT adalah suatu analisa yang membandingkan antara faktor eksternal peluang dan ancaman dengan faktor internal kekuatan dengan kelemahan. Hasil dari diagnosis SWOT terdiri dari empat sikap strategi perusahaan yang dapat diambil dari alternatif posisi perusahaan. Secara jelas, keempat strategi ini dapat dilihat pada gambar dibawah ini: 


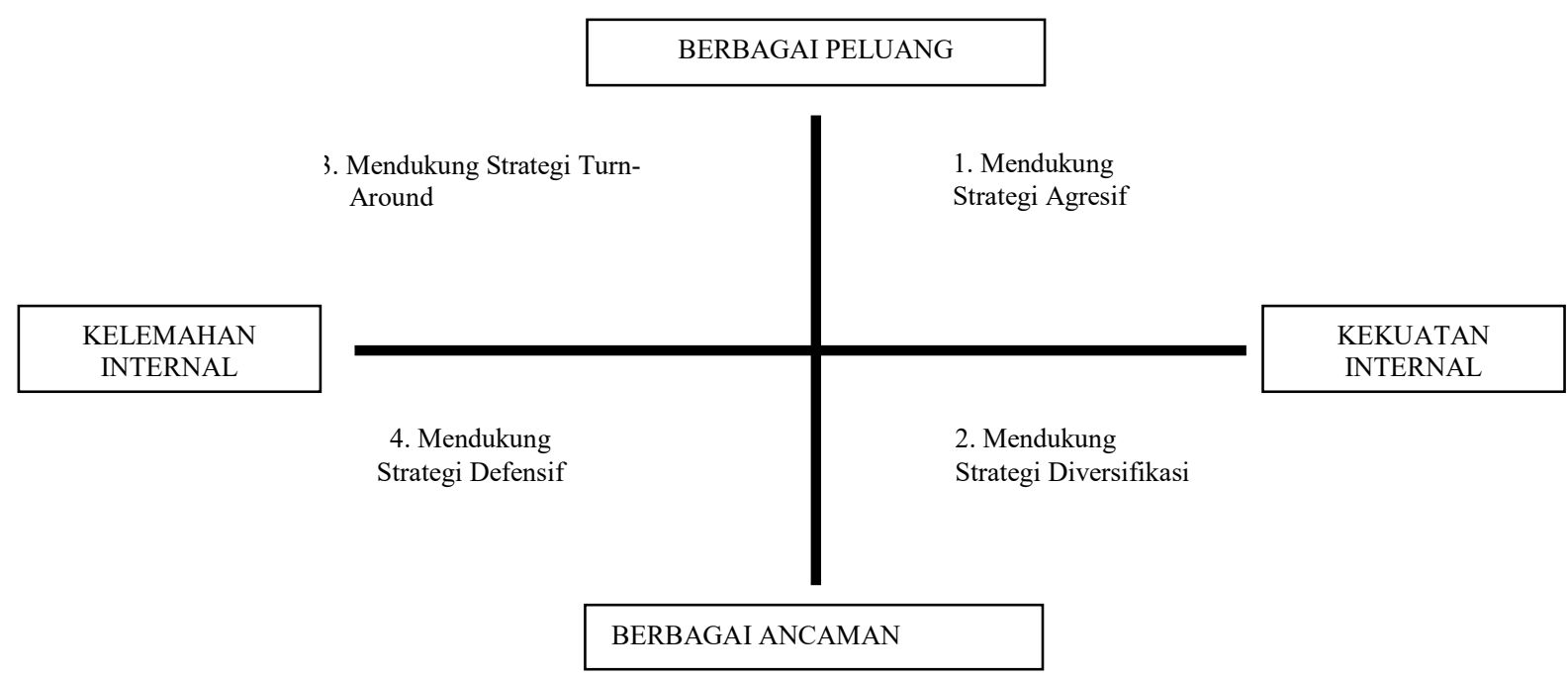

(Sumber : Rangkuti Freddy, Analisis SWOT Teknik Membedah kasus bisnis "Reorientasi Konsep Perencanaan Strategis untuk Menghadapi Abad 21”, Penerbit PT Gramedia Pustaka Utama Jakarta, 2001).

Penjelasan tiap kuadran adalah :

1. Kuadran I :

Merupakan situasi yang sangat menguntungkan perusahaan. Perusahaan mempunyai peluang dan kekuatan sehingga dapat memanfaatkan peluang yang ada. Strategi yang harus diterapkan dalam kondisi ini adalah mendukung kebijakan pertumbuhan yang agresif.

2.. Kuadran II.

Meskipun menghadapi berbagai ancaman, perusahaan masih mempunyai kekuatan internal. Strategi yang harus diterapkan adalah menggunakan kekuatan untuk memanfaatkan peluang jangka panjang dengan cara diversifikasi (produk/pasar).

3. Kuadran III.

Perusahaan menghadapi peluang pasar yang amat besar, tetapi di lain pihak ia menghadapi beberapa kendala/ kelemahan internal. Fokus strategi perusahaan ini adalah berusaha meminimalkan masalah-masalah internal perusahaan sehingga dapat merebut peluang pasar yang lebih baik.

4. Kuadran IV.

Merupakan situasi yang sangat tidak menguntungkan karena perusahaan menghadapi berbagai ancaman dan kelemahan internal.

\subsubsection{Analisis Strategi Internal, Internal Strategic Factor Analisys Summary (IFAS)}

Analisis ini memberikan suatu kesimpulan bahwa meskipun suatu kegiatan bisnis memiliki kekuatan yang tinggi di faktor tertentu, tetapi kekuatan ini tidak langsung berarti merupakan keunggulan bersaing.

\subsubsection{Analisis Strategi Eksternal, Eksternal Strategic Factor Analysis Summary (EFAS)}

Dalam melakukan analisis strategi eksternal yang terdiri dari peluang dan ancaman, perusahaan harus memantau kekuatan-kekuatan lingkungan makro (demografi, ekonomi, teknologi, politik, hukum, sosial budaya) yang berpengaruh terhadap jalannya usaha. Selain itu juga harus dipantau pemeran-pemeran lingkungan mikro yang signifikan (pelanggan, pemasok, pesaing, saluran distribusi) yang nantinya dapat mempengaruhi kemampuan perusahaan dalam meraih keuntungan.

Berbagai peluang tersebut harus dikelompokkan sesuai dengan daya tarik peluang itu dan kemungkinan keberhasilan yang akan diraih oleh perusahaan dari setiap peluang. Kemungkinan sukses yang diraih perusahaan dengan peluang tertentu, tergantung pada kekuatan perusahaan dalam memenuhi tuntutan sukses per- 
usahaan itu sendiri. Oleh karena itu perusahaan yang mampu memperagakan kemampuan terbaik akan menjadi perusahaan yang dapat meraih keunggulan bersaing.

\subsubsection{Cara Menyusun Formulasi Strategi}

Setelah mengumpulkan semua informasi yang berpengaruh terhadap kelangsungan perusahaan, tahap selanjutnya adalah memanfaatkan semua informasi tersebut dalam model-model kuantitatif perumusan strategi guna mencapai tujuan. Untuk itu digunakan berbagai model dan konsep analisis dengan tahapan proses sebagai berikut :
1.Menentukan faktor-faktor strategi internal dan strategi eksternal.

2.Untuk menentukan alternatif strategi yang sesuai bagi perusahaan adalah dengan cara membuat Matrik SWOT. Matrik SWOT ini dibuat berdasarkan hasil analisis faktor-faktor strategi, baik eksternal maupun internal yang terdiri faktor peluang, ancaman, kekuatan serta kelemahan.

\section{METODOLOGI PENELITIAN}

Penelitian ini dilakukan pada PT. Sinar Galesong Makassar sebagai salah satu dealer sepeda motor Suzuki di kota Makassar. Adapun kerangka masalah dapat dilihat sebagai berikut :

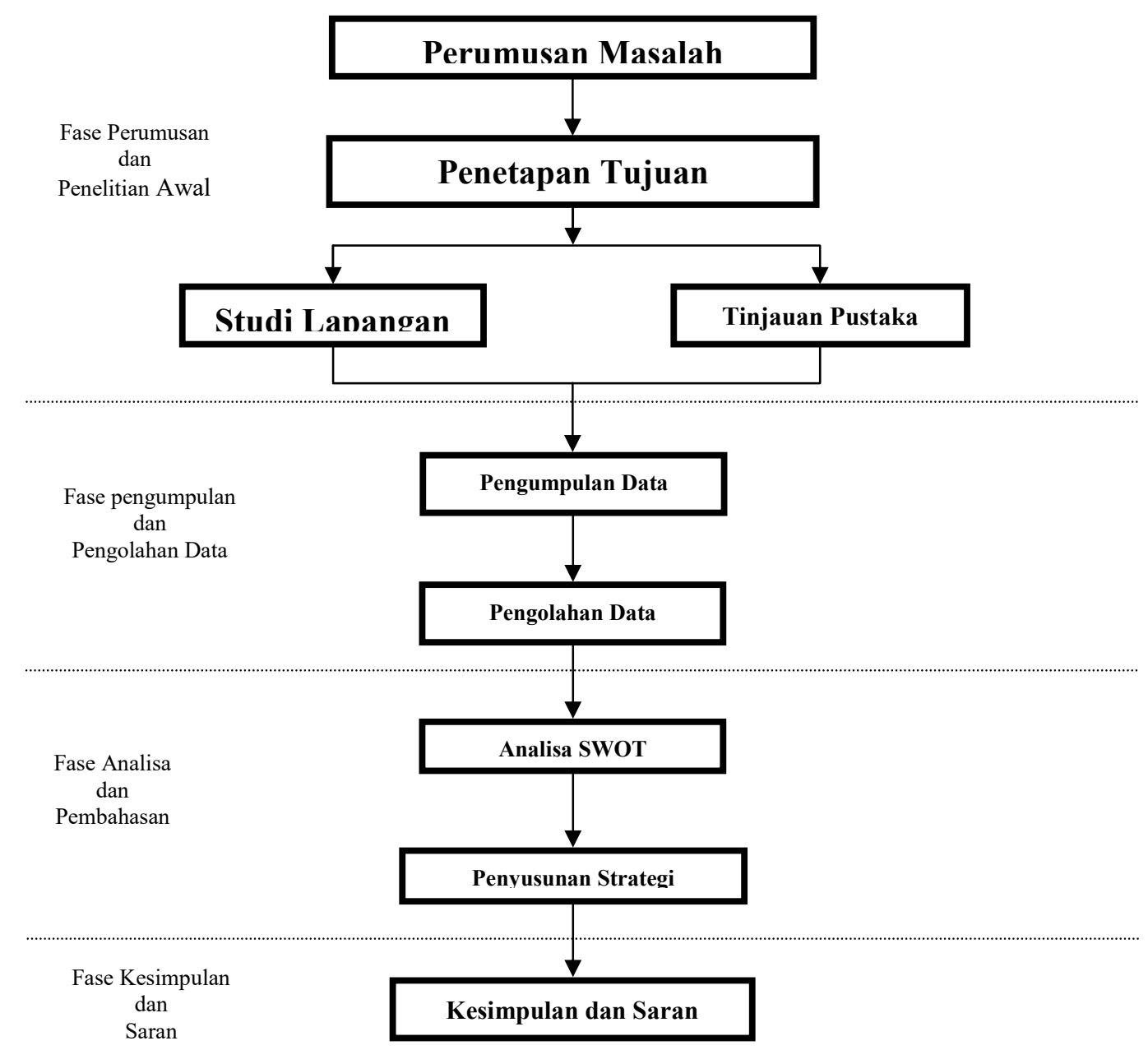

\section{PENGUMPULAN DAN PENGOLAHAN DATA}

Pengumpulan data dilakukan melalui nara sumber yang terkait dengan permasalahan volume penjualan pada tahun 2009 di PT. Sinar Galesong Makassar mengalami penurunan. Data-data yang diperoleh bersifat data sekunder. Adapun data penjualan motor Suzuki 
khususnya tipe Smash pada PT. Sinar Galesong Makassar dan PT. Nusantara Surya Sakti sebagai pesaingnya sebagai berikut :

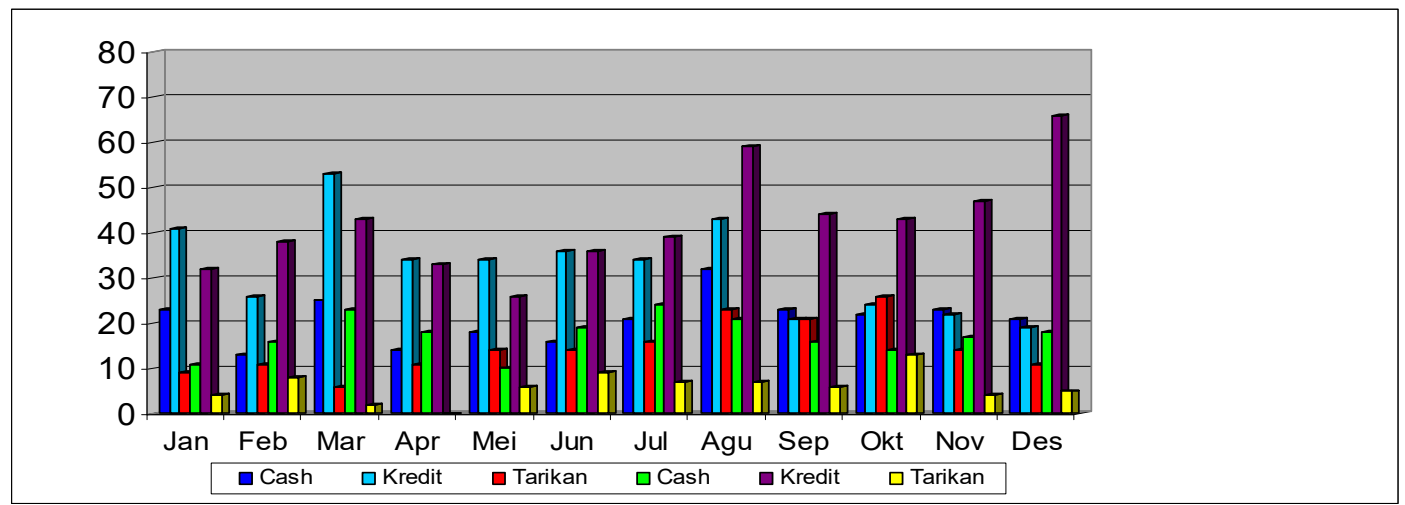

Keterangan: Untuk setiap warna yang pada gambar grafik yaitu menunjukkan penjualan bulanan pada tahun 2009 dari setiap perusahaan baik PT. Sinar Galesong Makassar maupun PT. Nusantara Surya Sakti.

PT. Nusantara Surya Sakti

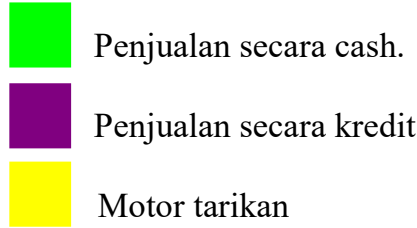

\subsection{Identifikasi Analisis SWOT}

Evaluasi dari perusahaan PT. Sinar Galesong Makassar dilakukan dengan menganalisa kekuatan, kelemahan, peluang dan ancaman dengan metode SWOT analisis sebagai berikut :

1. Strenght (kekuatan) adalah kemampuan yang dimiliki oleh lembaga secara internal, yang dapat didayagunakan untuk mendukung perkembangan.

a. Tipe/ model yang bervariasi, perusahaan PT. Sinar Galesong Makassar menawarkan beberapa tipe motor Suzuki tidak terpaku pada satu tipe motor saja

b. Komitmen pimpinan terhadap peningkatan mutu kedepan, dengan adanya pimpinan yang baru PT. Sinar Galesong Makassar yang mengadakan penelitian terhadap keinginan konsumen.

c. Tersediaan suku cadang/Suzuki Genuine Parts (HGP), membuat konsumen mudah unbtuk mendapatkan suku cadang asli Suzuki.
PT. Sinar Galesong Makassar

Penjualan secara cash.

Penjualan secara kredit

Motor tarikan

d. Harga yang bersaing, tidak akan meragukan konsumen karena sesuai dengan harga motor Suzuki dan dapat di jangkau.

e. Harga jual yang tinggi, membuat perusahaan tidak enggan untuk memasarkan kembali motor yang telah ditrarik dari konsumen sebelumnya. Memasarkan motor second.

f. Mesin awet \& irit BBM, ini merupakan keunggulan yang dimiliki oleh produk Suzuki sekaligus kejelian dari perusahaan membidik produk Suzuki tersebut

g. .Inovasi teknologi, selalu mengikuti perkembangan dan mengikuti selera konsumen.

h. Kemudahan kredit, membuat perusahaan selalu diajdikan pilihan utama oleh konsumen.

i. Discount harga dan Undian berhadiah, merupakan ransangan bagi konsumen untuk mem,ilih produk pada perusahaan

j. Citra perusahaan yang kuat/pengenalan nama karena PT. Sinar 
Galesong Makassar merupakan dealer Motor Suzuki yang pertama berada di Kota Makassar

2. Weakness (kelemahan), adalah semua aspek internal yang menghambat perkembangan lembaga.

a. Pengelolaan keuangan berdasarkan prinsip-prinsip keuangan, belum terkoordinir sesuai dengan manajemen keuangan.

b. Fasilitas perbangkelan yang dapat menunjang mekanik, sebagian masih menggunakan produk peralatan manual.

c. Program penelitian dan pengembangan usaha, sangat kurang dilakukan sehingga kurang memahami pangsa pasar yang ada.

d. Pelaksasnaan kegiatan pengabdian sosial kepada masyarakat, sangat kurang dialkukan.

e. Pengurusan surat-surat kendaraan, yang sering terlambat membuat konsumen mempertanyakan kinerja dari para karyawan.

f. Proses distribusi produk, letak geografis antara Makassar dan manado menyebabkan keterlambatan pendistribusian kendaran yang juga disebabkan oleh kurangnya pengecekan dibagian gudang.

g. Jumlah karyawan yang tidak memadai, membuat karyawan tidak mampu melayani konsumen dengan pelayanan yang prima.

h. Motivasi kerja dari perusahaan terhadap karyawan, sangat kurang dilakukan hanya pada saat menjelang perayaan hari besar keagamaan menyebabkan karyawan tidak bekerja dengan maksimal.

i. Jumlah armada penjualan, tidak sesuai dengan kebutuhan perusahaan.

j. Bentuk promosi yang dilakukan perusahaan, masih sangat kurang dilakukan atau dengan kata lain tidak ada keseriusan dari pihak perusahaan untuk melakukan kegiatan promosi.

3. Opportinities (peluang), adalah kecenderungan eksternal yang memberikan pengaruh positif pada PT. Sinar Galesong Makassar

a. Dimekarkannya Bolaang Mongondow menjadi beberapa wilayah, merupakan kesempatan untuk melakukan ekspansi perusahaan di daerah yang baru dimekarkan.

b. Penyedia suku cadang asli Suzuki genuine parts (HGP), adalah salah satu peluang untuk dapat memanjakan konsumen dengan suku cadang asli Suzuki.

c. Kebijakan pemerintah (PERDA) terhadap alat transportasi darat yaitu becak motor (Bentor), dengan melegalkan Bentor yang merupakan alat transportasi darat dengan modifikasi motor, tentunya membuka peluang kerja dan mengurangi tingkat pengangguran yang.

d. Pasar motor 4 Tak yang tumbuh cukup besar karena ramah lingkungan.

e. Memiliki citra merk yang kuat.

f. Mendapat dukungan penuh dari pemerintah.

g. Stabilitas politik dan tumbuhnya daya beli masyarakat.

h. Berkemgangnya tempat-tempat pemukiman penduduk (Perumahan) yang merupakan pertumbuhan baru atau pengembangan usaha.

i. Adanya perubahan gaya hidup masyarakat sehubungan dengan tumbuhnya tingkat perekonomian.

4. Threat (ancaman), adalah kecenderungan eksternal yang dapat menghambat perkembangan PT. Sinar Galesong Makassar itu sendiri.

a. Banyaknya jasa servis yang tersedia dan penjualan suku cadang yang bukan asli Suzuki, yang dapat merusak citra merk Suzuki karena 
dengan demikina kendaraan yang sudah tidak menggunakan suku cadang asli hon tentunya tidak akan bertahan sesuai dengan motor Suzuki yang masih menggunakan suku cadang asli hoda.

b. Strategi bisnis mudah ditiru oleh pesaing, tentunya perusahaan harus selalu melakukan perubahan strategi dalam pemasaran.

c. Perilaku atau sikap konsumen yang cenderung berubah-rubah setiap saat (selera konsumen).

d. Munculnya perusahaan-perusahaan baru dengan produk yang sejenis.

e. Perkembangan teknologi yang sangat cepat, apabila tidak diikuti akan membuat perusahaan ketinggalan terutama dibidang pelayanan yang sudah serba digital.

f. Tuntutan konsumen akan pelayanan yang lebih baik, tentunya apabila konsumen tidak mendapatkan pelayanan yang prima ini akan membuat citra perusahaan akan tercoreng.

g. Pembengkakan biaya operasional diakibatkan makin banyaknya pungli.

h. Konsumen semakin sensitive terhadap harga, perubahan harga yang diakibatkan oleh biaya operasional yang membengkak akan berpengaruh langsung kepada konsumen.

i. Kurangnya pemngetahuan masyarakat untuk menentukan jenis motor yang sesuai dengan kebutuhan, tidak adanya sosialisasi yang dilakukan oleh perusahan dengan akn motor yang sesuai dengan kebutuhan.

j. Kemungkinan berpindahnya tenaga kerja ke perusahan lain, diakibatkan oleh berbagai macam alasan.

\section{ANALISA DAN PEMBAHASAN}

Pada bab ini dilakukan analisa dan pembahasan dari bab sebelumnya yaitu ; merupakan analisa terhadap SWOT (Strenght, Weakness, Opportuni- ty, Threat), pada PT. Sinar Galesong Makassar Makassar. Setelah dibuat dan diketahui nilai dari jumlah bobot, rating dan skor tiap-tiap faktor strategis perusahaan PT. Sinar Galesong Makassar. Kemudian di masukkan kedalam Tabel perbandingan matrik kompetitif untuk dapat mengetahui sejauh mana kekuatan, kelemahan, peluang dan ancaman (SWOT) dari perusahaan yang dianalisis dalam hal ini PT. Sinar Galesong Makassar dibandingkan dengan PT. Nusantara Surya Sakti yang dijadikan sebagai pesaing karena berada pada posisi yang sama sebagai dealer resmi Motor Suzuki yang ada di Kota Makassar.

- Perbandingan Matrik Kompetitif Faktor Strategi Internal PT. Sinar Galesong Makassar dan PT. Nusantara Surya Sakti

Secara umum perbedaan faktor kekuatan kedua perusahaan tidak menunjukkan perbedaan yang sangat signifikan, keunggulan PT. Sinar Galesong Makassar (Perusahaan yang ditelitit/dianalisis) terletak pada citra nama perusahaan/pengenalan nama karena semenjak tahun 2001 perusahaan ini telah didirikan, akan tetapi seiring dengan bergulirnya waktu dari segi faktor kekuatan PT.Sinar Galesong Makassar lemah dari segi penyediaan suku cadang asli Suzuki (HGP) dan penawaran harga. Sedangkan dari segi faktor internal (faktor kelemahan) juag terlehat kelemahan yang dimiliki oleh PT. Sinar Galesong Makassar sudah memprihatikan (1.186) bandingkan dengan PT. Nusantara Surya Sakti (2.290) Faktor yang sangat lemah pada internal perusahaan PT. Sinar Galesong Makassar terletak pada pengelolaan keuangan, kurangnya promosi yang dilakukan, serta keterlambatan dalam pengurusan surat-surat kendaran.

- Perbandingan Matrik Kompetitif Faktor Strategi Eksternal PT. Sinar Galesong Makassar dan PT. Nusantara Surya Sakti 
Secara keseluruhan hasil dari perhitungan bobot, rating dan skor dan total dari semua Faktor yang ada baik Faktor secara internal (kekuatan dan kelemahan) serta Faktor eksternal (peluang dan ancaman) dapat dilihat bahwa keunggulan rata-tara berada pada PT. Nusantara Surya Sakti (6.531) sedangakan PT. Sinar Galesong Makassar (5.212), keunggulan hanya terletak pada Faktor eksternal (peluang) yang dimiliki lebih baik dibandingkan dengan PT. Nusantara Surya Sakti.

\section{Diagram SWOT}

Analisa SWOT yaitu mengidentifikasi berbagai faktor untuk merumuskan strategi. Analisa ini didasarkan pada usaha untuk memaksimalkan kekuatan dan peluang, namun secara bersamaan dapat meminimalkan kelemahan dan ancaman.

Berdasarkan data faktor-faktor internal dan eksternal didapatkan skor pembobotan sebagai berikut :

1. Faktor kekuatan $=1,419$

2. Faktor kelemahan $=1.186$

3. Faktor peluang $=1.284$

4. Faktor ancaman $=1.323$
Dari skor pembobotan diatas selanjutnya diplot pada gambar analisa diagram SWOT yang terdiri dari 4 kuadran yaitu :

1. Kuadran $I=$ merupakan strategi agresif adalah digunakan kekuatan untuk mengambil manfaat dari peluang yang ada

2. Kuadran II = merupakan startegi diversifikasi adalah gunakan kekuatan untuk menangkal ancaman

3. Kuadran III $=$ merupakan strategi turn-around adalah mengatasi kelemahan dengan mengambil manfaat dari peluang yang ada

4. Kuadran IV $=$ merupakan strategi defensif adalah mengatasi ancaman dengan memperbaiki kelemahan

Untuk dapat mengetahui pada koordinat berapa letak dari Faktor strategis yag akan di dapat terlebih dahulu titentukan titik kordinat sebagai berikut : $1.419-1.186 / 2=0.1165$ atau 0.117 $1.284-1.323 / 2=0.0195$ atau 0.020 .

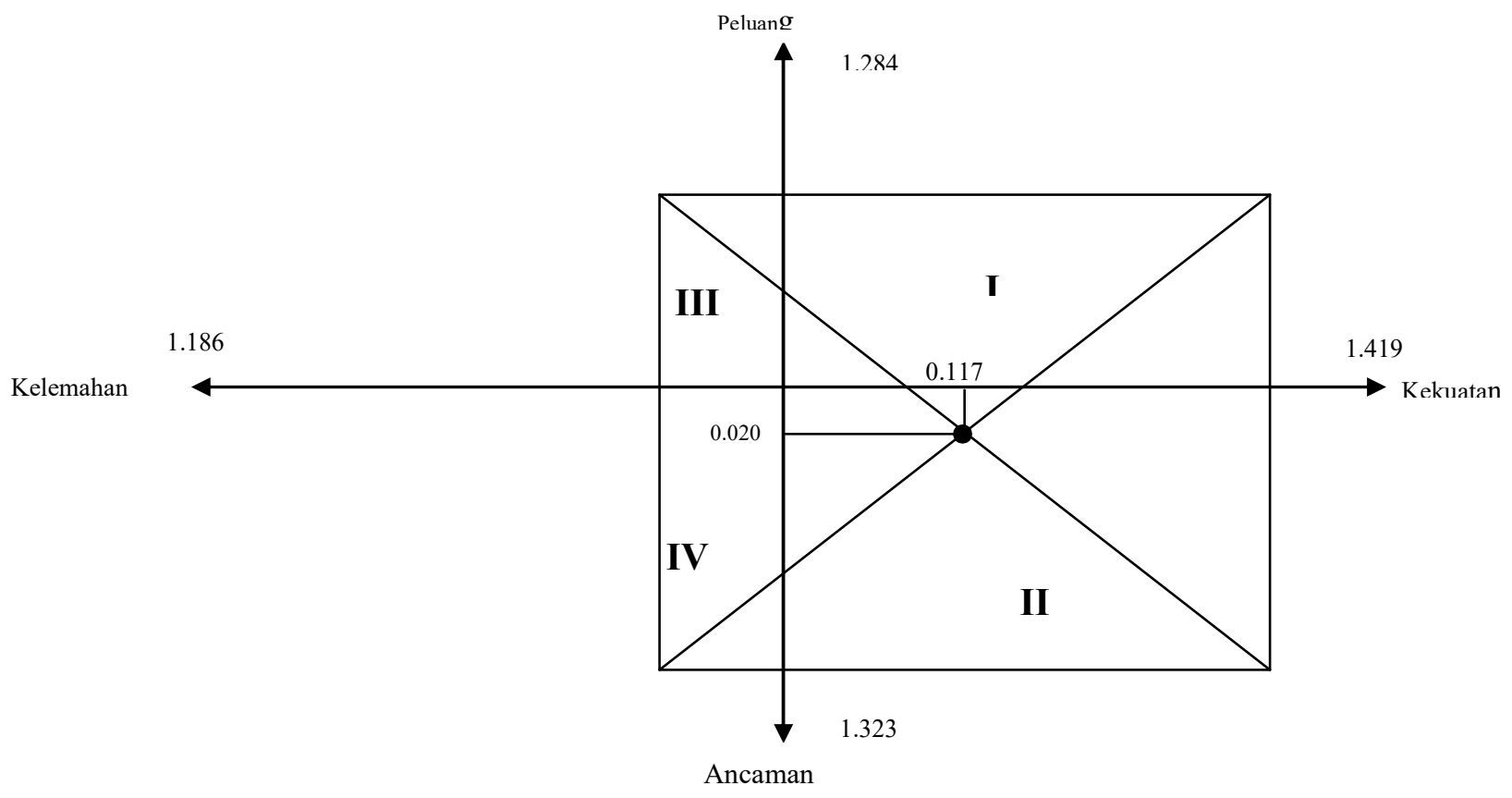

Gambar 5.1. Analisa Diagram SWOT 
Dari perpotongan keempat garis faktor kekuatan, kelemahan, peluang dan ancaman, maka didapatkan koordinat $(0,117$ : 0,020) pada kuadran II yaitu : Strategi Diversifikasi.

\section{A. Analisa Diagram (PETA) SWOT}

Setelah dilakukan pengeplotan yang nampak pada gambar 5.1, maka dapat dianalisa sebagai berikut :

1. Koordinat $(\mathbf{0 , 1 1 7}: \mathbf{0 , 0 2 0}$ yang merupakan hasil persilangan pengeplotan skor pembobotan faktor kekuatan $=1,419$, faktor kelemahan $=1,186$, faktor peluang $=1,284$, dan faktor ancaman $=$ 1.323 terletak pada kuadran II (dua) akan tetapi sangat dekat dengan kuadran I seperti terlihat pada tabel 5.4.

Hal ini menunjukkan perusahaan PT. Sinar Galesong Makassar menerapkan Sterategi Diversifikasi, yaitu :

2. Mengerahkan semua faktor internal (kekuatan) yang ada demi menanggapi faktor eksternal (ancaman) dengan lebih memperhatikan dan memberikan pelayanan yang prima kepada konsumen terlebih perusahaan harus memperhatikan keinginan konsumen tanpa mengabaikan strategi dari perusahaan lain dan hadirnya perusahan baru dengan produk yang sejenis (dealer motor Suzuki yang baru).

3. Koordinat $(\mathbf{0 , 1 1 7}: \mathbf{0 , 0 2 0})$ yang letaknya pada kuadran II (dua) merupakan faktor potensial dari internal (kekuatan) yang dimiliki oleh perusahaan PT. Sinar Galesong Makassar Makassar seperti :

Perusahaan menjual motor dengan mengedepankan kualitas karena memiliki mesin yang baik dan irit bahan bakar minyak, kemudian di topang oleh adanya pimpinan baru PT. Sinar Galesong Makassar yang memiliki komitmen terhadap masa depan perusahaan.

Tetapi disisi lain ada faktor eksternal (ancaman) yang harus dihadapi oleh perusahaan PT. Sinar Galesong Makassar, seperti :
- Pembengkakan biaya operasional yang diakibatkan oleh maraknya pungli yang menyebabkan biaya perusahaan berlipat ganda hal ini nantinya akan sangat berpengaruh terhadap kondisi internal perusahan.

- Berpindahnya tenaga kerja ke perusahaan lain dikeranakan oleh kurangnya motivasi kerja dari perusahaan

- Strategi bisnis yang mudah ditiru oleh perusahaan lain akan menyebabkan kerugian besar Karena akan berpindahnya konsumen ke perusahaan lain yang sejenis diakibatkan oleh tuntutan konsumen terhadap pelayan yang prima.

\section{KESIMPULAN}

\section{Kesimpulan}

Dari hasil pengolahan dan analisa yang telah dilakukan maka dari penelitian ini dapat diambil beberapa kesimpulan. Dimana kesimpulan-kesimpulan ini diharapkan dapat memberikan konstribusi pada kepentingan perusahaan dan kepentingan penelitian-penelitian berikutnya. Adapun kesimpulannya sebagai berikut :

Pada diagram SWOT, titik koordinat $(0.117: 0.020)$ yang letaknya pada kuadran II (Kedua) merupakan faktor potensial dari faktor internal (kekuatan) dan faktor eksternal (ancaman) yang dimiliki oleh PT. Sinar Galesong Makassar Makassar yaitu dengan menerapkan Strategi Diversifikasi.

Penetapan strategi alternatif yang bisa diambil berdasarkan prioritas adalah : (1). Strategi kekuatan dan ancaman (Aku) ST (2). Strategi kekuatan dan peluang (Peku) SO (3). Strategi kelemahan dan ancaman (Aka) WT (4). Strategi ancaman dengan kelemahan (Peka) WO.

Menerapkan strategi Buyyer Market yaitu, tidak lagi hanya menunggu pembeli akan tetapi menjemput pelanggan dengan cara melakukan lebih aktif promosi berupa pemasangan iklan/reklame di TV Lokal, 
Radio, memasang spanduk ditempat-tempat keramaian dan strategis yang dapat dengan mudah dilihat oleh calon konsumen, membagikan famplet yang berisi kemudahan persyaratan kredit, undian berhadiah, menawarkan hadiah langsung kepada konsumen (Cash Back), karena PT. Sinar Galesong Makassar dalam hal ini juga merupakan perusahaan yang menawarkan jasa, oleh karena itu sebaiknya juga menawarkan servis langsung kepada konsumen.

\section{DAFTAR PUSTAKA}

Angipora Marius P. 2002, Dasar-Dasar Pemasaran, edisi revisi, cetakan kedua, Penerbit, Raja Grafindo, Jakarta

Assauri, Sofyan. 1999, Manajemen Pemasaran : Dasar, Konsep dan Strategi, cetakan keenam, Penerbit, Raja Grafindo, Jakarta

Charles W. Lamb. 2001, Pemasaran, Buku 1, Penerbit, Salemba Empat, Jakarta

Chandra Gregorius. 2002, Strategi Program Pemasaran, edisi pertama, cetakan pertama, Penerbit, Andi Ofset, Yogyakarta

Harper W. Boyd. 2000, Manajemen Pemasaran : Satu Pendekatan
Strategis Dengan Orientasi Global, edisi kedua, jilid satu, Penerbit, Erlangga, Jakarta

Gitosudarmo, Indriyo. 2000, Manajemen Pemasaran, edisi pertama cetakan keenam, Penerbit, BPFE, Yogyakarta

Kotler, Philip. 2002, Manajemen Pemasaran_ edisi Milenium, Penerbit, Prenhallindo, Jakarta

Nusran, Muhammad. 2004-2005, Startegi Industri, Penerbit Al-Qalam @ 2004 Production

Rangkuti Freddy, Analisis SWOT Teknik Membedah kasus bisnis "Reorientasi Konsep Perencanaan Strategis untuk Menghadapi Abad 21", Penerbit, PT Gramedia Pustaka Utama, Jakarta

Riduwan, dan Akdon, 2005, Rumus dan Data dalam Aplikasi Statistika, Penerbit Alfabeta

Swastha, Basu dan Irawan. 1997, Manajemen Pemasaran Modern, Penerbit, Liberty, Yogjakarta

*) Penulis adalah Dosen Tetap STIE Nobel Indonesia Makassar 